\title{
Interest in Islamicpreneur: Family Environment Factors and Religiosity Analysis (The Research of Islamic Economics Students at University in Bandung)
}

\section{Elmi Akmalianis, A. Jajang W. Mahri, Neni Sri Wulandari, and Dudi Septiadi}

Economics and Islamic Finance Department, Universitas Pendidikan Indonesia, Jl. Dr. Setiabudhi No. 229 Kota Bandung

\section{Abstract}

Entrepreneurship is one of the occupation that has a noble in the view of Islam. In addition, Entrepreneurship is also has an important role for the welfore of a state. Howover, the entrepreneurship ratio in Indonesia is still in low rate compared to another countries. For the reason, this research will discuss student's interest toward Islamicpreneur. It is because students' interest in islamicpreneur is the source for

Corresponding Author:

Elmi Akmalianis

elmiakmalianis@gmail.com

Received: 10 February 2019

Accepted: 14 March 2019

Published: 28 March 2019

Publishing services provided by Knowledge E

(c) Elmi Akmalianis et al. This article is distributed under the terms of the Creative Commons Attribution License, which permits unrestricted use and redistribution provided that the original author and source are credited.

Selection and Peer-review under the responsibility of the ICIEBP Conference Committee. the birth of Islamic entrepreneurs in the future. Based on the previous research, entrepreneurial interest is influenced by among others, family enviroment and religiousity level. Therefore this research aims to analyze and predict the influence of family enviroment and religiousity toward students interests in islamicpreneur. The population of this research is the student of Islamic economics at university in Bandung. The study use non-probability-accidental sampling as sampling technique with 280 people as the subjects of the research. Then the research was using causality method with quantitative approach. The data was analyzed using Partial Least SquaresStructural Equation Modeling (PLS-SEM). The results showed that the family environment has a positive and significant effect on the interest of Islamicpreneur, while the level of religiosity does not affect the interest of Islamic scholars. This research is expected to be able to provide benefits to various parties in increasing the interest of Islamic scholarship in students, especially Islamic economics students at University in Bandung.

Keywords: Family Enviroment, Religiosity, Student Interest in Islamicpreneur

\section{Introduction}

Unemployment phenomenon still become main issue for Indonesia until now (Muhdar 2015). Badan Pusat Statistika (BPS) record in 2017 unemployment numbers increase until 10.000 people. Until now, unemployment people in Indonesia records as 7,04 million people in August 2017 (BPS, 2017). Head of BPS Kecuk Suhariyanto say, the 
increase number of unemployment people caused by increased workforce not followed by increased jobs (Kompas, 2017).

The effort from policy makers to overcome the problem are grow entrepreneur activity in community (Kemendagri. 2013). However Head of Komisi Pengawas Persaingan Usaha (KPPU) M. Syarkawi Rauf explain about entrepreneur activity in Indonesia not able to give positive effect for unemployment phenomenon and public welfare. Minister of Koperasi dan Usaha Kecil Menengah, Anak Agung Gede Ngurah Puspayoga said entrepreneur ratio in Indonesia still below other country there's 1,6\% whereas US 12\%, Japan 11\%, China 110\%, Singapore 7\% and Malaysia 5\% (Repiblika, 2017). According David McCleland those numbers still not make one country be prosperous country. David Said one of the terms is there must be $2 \%$ entrepreneur of all population in the nation (Depkop, 2017).

Moreover, the Other problem is still lack of Muslim Entrepreneurs in Indonesia. Globe Asia Magazine report between 150 richest entrepreneur in Indonesia only 24 entrepreneurs from Muslim community and the rest are non-Islamic person (Republika. 2017) This is a concern, because Indonesia is the counry with the biggest Muslim community in the world 2015). With 209,120 million Muslim people, Indonesia has to be entrepreneurial country (Ramdhani, 2017). Entrepreneurship is a noble from Islamic economic vision for work. Juliana (2017) said that Islam is a religion that encourages people become entrepreneurs. Furthermore Islam encourages people to find gifts from Allah. This expression is in line with Allah commandment in al-Qur'an:

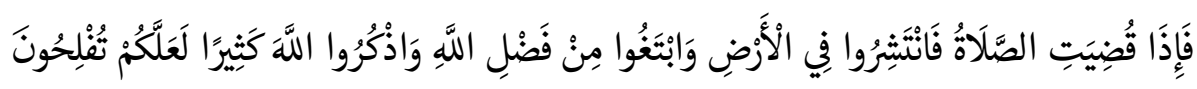

Artinya: "And when the prayer has been concluded, disperse within the land and seek from the bounty of Allah, and remember Allah often that you may succeed.." (QS. Al-Jumu'ah:10)

Other than that, Rasulullah explain the noble of a muslim become entrepreneur, as history from Rafi' bin Khadij he said there is someone ask to Rasulullah: 'O Rasulullah, what is the best job?' Rasulullah answer: "a work done by someone, with the hand and legal trade (well)" (History Hadits Al Baihaqi in Al Kubra 5/263, validated Al Albani in As Shahihah pedigree 607)

In the reality, this is not an easy case for creating entrepreneurs in Indonesia. People in Indonesia more confidence to work for someone rather than do their own business. The education in Indonesia shapes student to become an employees or work in offices. During the study period, students in Indonesia tend to prepare their self for find work not to open a jobd (Nurkholifah \& Ita, 2014) 
Chairman of Indonesia Young Entrepreneur Community, Bahlil Lahadila saidbased on the data studied, there were 5 million of Indonesian students. Only $4 \%$ of the students choose to be an entrepreneur $83 \%$ choose to become employees and the rest become politicians (Merdeka, 2017)

Another problem in Indonesian entrepreneur sector is many entrepreneurial models developed still refer to conventional models that do not include religion as one of the basic principles in entrepreneurship (Juliana 2017). Besides, Nurkhalifah \& Ita (2014) in the research about Muslim Entrepreneurship revealed that if we want to follow the concept that is ordered by Islam as a religion that glorifies people in the world, of course Indonesia can answer all of the welfare issues by immediately creating muslim entrepreneurship in Indonesia. This followed by the research from Juliana (2017) that said Islamic entrepreneur influence the welfare of society.

Parallel with the reality, it is important to increase student interest, especially for student of Islamic Economics department towards Islamic Entrepreneurship. Because student interest of entrepreneurship is the source of the birth of future entrepreneur. Interest in entrepreneurship is not owned from birth, nonetheless developed with factors. Based on previous research, one factor is influenced by family environment and religiosity. Family environment is the first environment that has a profound impact on the children. (Yanti Nuridja \& Dunia, 2014)

Hisrich (2008) on his research said that 725 entrepreneurs studied had parents who were relatively close to entrepreneurs sector. This means, that the family environment is one of the effective factors to foster interest in entrepreneurship. The expression supported by research from Wahyuningsih (2017), Maftuhah (2015), Siam \& Ibrahim (2015) and Yanti (2014) found that the family environment has a positive and significant influence on the interest of entrepreneur.

Farther, based on research from other country, the interest of entrepreneurship influenced by level of religiosity. Religiosity described by how far individuals have a commitment to approve and apply dogma by reflecting behaviour in life (Sungkar, 2010). This is supported and in line with the research from Balog (2013), Abdullahi (2015), Riaz (2016) and Youcef (2015), said that religiosity factor has a positive and significant influence on the interest of entrepreneur

In Indonesia, research about the influence of the level of religiosity on interest in entrepreneurship is still very limited. Ramdani (2017) in his research, it was revealed that the level of religiosity did not significantly influence the tendency of a Muslim to become an entrepreneur. So this attracts researchers to examine more deeply the level of religiosity towards entrepreneurial interest. 
Based on the research results and problems of the phenomenon before, then the author is interested in researching how the condition of family environment, the level of religiosity and the interest of Islamicpreneur among Islamic economics students in Bandung. And aslo how far the family environment and religiousity level influences the interest of Islamicpreneur among Islamic economics student in Bandung.

\section{Literatur Review}

Islamicpreneur is standard term that always discussed as main topic in Islamic economics development in many country. This standard term appear from main idea and practice about Islamic entrepreneurship campaign by muslim entrepreneur wich have motivation and encouragement for increasing good donation in current production, distribution and consumption for goods and services in Islamic values (Makhrus \& Cahyani, 2017).

Hidayat (2017) define Islamicpreneur as a person who can exploring factor of production and still stand on Islamic values in the corridor business ethic which can produce idea, goods and services for consumer consumption with Halal and Thayib principle, good in terms of halal substances where the purpose of the entrepreneur not only chasing profits but also chasing benefit with staying away from things that prohibited in Islam. Later, Makhrus (2017) express that Islamicpreneur is an entrepreneur which always have viewpoints that all business activities still bound with fundamental, value and self-means to get close to Allah. Agree with Wulandari (2016) which states that sharia-creativepreneur is a person who entrepreneurial based on motives pray to Allah SWT and not driven by rational and materialism motives.

Basically there have not been many studies that reveal the notion of interest in Islam in particular, for this reason researchers develop the concept of entrepreneurial interest in general as a basis for understanding the interests of Islamists. As for the interest in entrepreneurship is defined as a person's choice of activities because they feel interested, excited and eager to entrepreneurship and risk-taking to achieve success (Yanti, Nuridja, \& Dunia, 2014

Therefore, based on self-development from entrepreneurial interest concept associated with the understanding of Islamicpreneur, the research concludes that Interest of Islamicpreneur is an impulse that arises in itself because feel interest, happy and willing to create a business by exploring production factors based on sharia in the corridor Islamic business ethics and dare to take risk to achieve success (Yanti, Nuridja \& Dunia, 2014) and (Hidayat \& Alhifni, 2017). The indicators of interest in Islam are based on the 
development of the concept of entrepreneurial interest delivered by (Yanti, Nuridja, \& Dunia, 2014) among them:

1. Making activity choice

2. Interested in entrepreneurship in Islam

3. Feeling happy for entrepreneurship in Islam

4. Willing to entrepreneurship in Islam

5. Dare to take risk

Family environment is the main activity place of a person's life takes place, for that family is a determinant in one's self-development (Bucori, 2007).Wherein there are activities that include the way parents educate, relationships between families, the atmosphere of the house, and family economic activities. (Slameto, 2010). Octavianica (2016) in her research express that environment has big effect for an entrepreneur. This is explained in Convergence Theory that declare environment has big effect for self-development (Walgito, 2002).

This opinion later supported by final result of a research which is conducted by Wahyuningsih (2017), Maftuhah (2015), Ayodale (2014), Mustapha (2015) and also Yanti (2014). The final results of the research explained that family environment has positive influence on entrepreneurship interest. As for the indicators from family environment is:

1. The way parents educated

2. Relation between family

3. Home atmosphere

4. Family economic circumstances

5. Parents understanding

6. Cultural Background

Religiosity is level of religious internalization of a person seen from appreciation of the faith, shari'a and someone behaviour (Aisyah, 2014). Later, Sungkar express that religiosity is explained by how far individuals have a commitment to approve and apply dogma by reflecting behaviour in life (Sungkar, 2010). Linkages from religiosity towards Islamicpreneur interest based on research which is conducted by Balog (2013), Abdullahi (2015), Riaz (2016), and also Youcef (2015) said that religiosity factor has a positive and significant influence on the interest of entrepreneur. Other than that, Brow on (Fauzan, 
2013) express the factor of religiosity have a considerable influence in shaping ethical behavior in doing business. As for being an indicator of deep religiosity in this research is:

1. Habluminnallah behavior (Aisyah, 2014).

2. Habluminnanas behavior (Aisyah, 2014).

3. Habluminnanafsi behavior (Juliana, 2014).

\section{Methodology}

The method used on this research is survey method with explanatory approach. This research uses hypothesis testing design, then a suitable design for this research is causality design. This research was conducted in Bandung between July until August 2018 with the research population is Islamic economics student from Universitas Pendidikan Indonesia, Universitas Padjajaran and Universitas Islam Negeri Sunan Gunung Djati with the total 950 people as a population Based on solvin formula, obtained as many as 280 samples.

With non-probability-accidental sampling used by this research. Collecting data method is using questionnaire. The instrument used for this research using scoring in the form of likert scale with score range between 1-5 who represent very agree-strongly disagree also always-never range.

The data analysis technique used is descriptive technique and analysis of Patrial Least Square-Structural Equation Modeling (PLS-SEM) with the help of SmartPLS 3.0 tools.

\section{Result}

\subsection{Family environment}

Based on the calculation of the field data, it can be seen that the family environment variable of each respondent is in the high tendency category with a percentage of $67 \%$ or as many as 188 students. While in the medium category that is equal to $33 \%$ or as many as 92 students. Thus it can be said that the role of the family environment has a sizeable proportion of the interest of a student to become Islamicpreneur. 


\subsection{Religiosity}

Based on the calculation of field results data it can be seen that it can be seen that the religiosity variables of each respondent are in the high tendency category with a percentage of $70 \%$ or as many as 195 students. While in the medium category that is equal to $30 \%$ or as many as 85 students. Thus it can be said that, Islam Economics college students in Bandung have obedience in worshiping well. This is because the cultural environment created in Islamic economic lectures is certainly Islamic.

\subsection{Partial least squares - Structural equation modelling (PLS- SEM) analysis}

\subsubsection{Outer model test}

Testing the outer model is a test to explain the relationship between latent variables and indicators. the stages that need to be analyzed in testing the outer model include:

\section{Convergent Validity}

Convergent validity is a tool used to measure reflective validity as a measure of variables that can be seen through the outer loading value of each variable indicator ( Juliana, 2017). According to Ghazali (2014) Indicator is said to be valid if loading factor $>0.70$.

Based on the above output, it can be said that the research indicator does not have convergent validity problems. So that this test deserves to proceed to the next stage.

\section{Descriminant Validity}

Discriminant validity testing is done through Fornell-Lacker Criterion analysis, which is a validity test that is done by comparing the correlation between variables or constructs with the square root of Average Variance Extracted $(\sqrt{ })$. Predictions are said to have a good AVE value if the square root value AVE of each latent variable is greater than the correlation between other latent variables. The following is a table Fornell-Lacker.

Besides that another method that can be used to measure discriminant validity is through analysis cross-loading.

From the test results with cross loading in Table 3 it can be seen that the correlation of each construct with its indicator is greater than the correlation of each construct with 
TABLE 1: Loading factor.

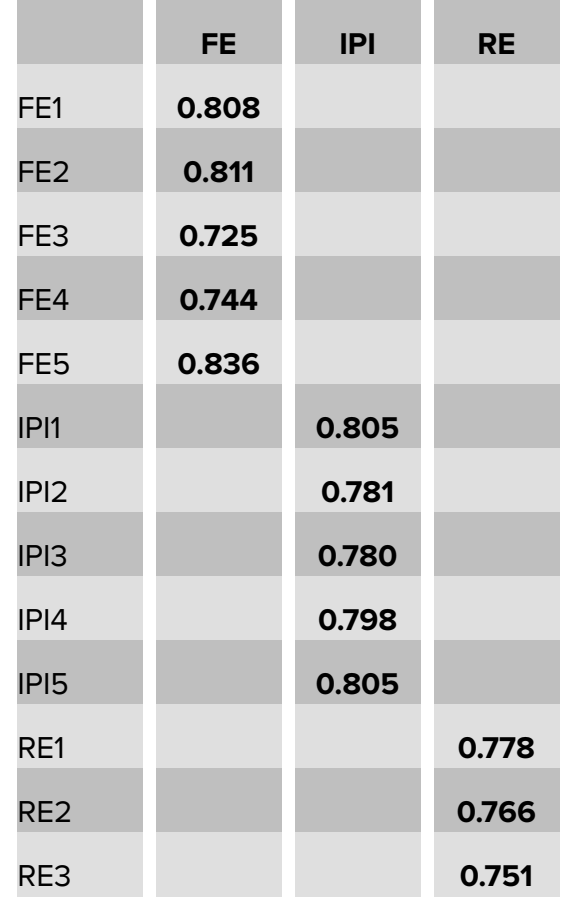

TABLE 2: Fornell-Lacker Criaterion.

\begin{tabular}{|l|c|c|c|} 
& FE & IPI & RE \\
\hline FE (X1) & $\mathbf{0 . 7 9 2}$ & & \\
\hline IPI (Y) & 0.700 & $\mathbf{0 . 7 9 4}$ & \\
\hline RE (X2) & 0.425 & 0.316 & $\mathbf{0 . 7 6 5}$ \\
\hline
\end{tabular}

other construct indicators. From the results of the second analysis, it can be concluded that all constructs in the estimated model meet the criteria of discriminant validity.

\section{Average Variance Extracted (AVE)}

Garson (2016) explained that the AVE value must be above 0.50 , which value reveals that at least the latent factor is able to explain each indicator by half of the variance. Here is the value of AVE in the study:

Based on the above output it can be seen that the AVE value exceeds 0.50 . Thus it can be concluded that all latent variables in this study are said to be good in representing indicators

\section{Composite Realibility}

This analysis aims to ensure that there are no problems associated with measuring reliability. The study is free from the problem of reliability when the composite reliability and cronbach's alpha value is more than 0.70 (Ghozali, 2014). Nevertheless 
TABLE 3: cross-loading

\begin{tabular}{|l|c|c|c|}
\hline & FE & IPI & RE \\
\hline FE1 & $\mathbf{0 . 8 0 8}$ & 0.602 & 0.383 \\
\hline FE2 & $\mathbf{0 . 8 1 1}$ & 0.503 & 0.304 \\
\hline FE3 & $\mathbf{0 . 7 2 5}$ & 0.412 & 0.247 \\
\hline FE4 & $\mathbf{0 . 7 4 4}$ & 0.570 & 0.344 \\
\hline FE5 & $\mathbf{0 . 8 3 6}$ & 0.639 & 0.377 \\
\hline IPI1 & 0.568 & $\mathbf{0 . 8 0 5}$ & 0.252 \\
\hline IPI2 & 0.506 & $\mathbf{0 . 7 8 1}$ & 0.200 \\
\hline IPI3 & 0.500 & $\mathbf{0 . 7 8 0}$ & 0.220 \\
\hline IPI4 & 0.614 & $\mathbf{0 . 7 9 8}$ & 0.320 \\
\hline IPI5 & 0.576 & $\mathbf{0 . 8 0 5}$ & 0.248 \\
\hline RE1 & 0.347 & 0.239 & $\mathbf{0 . 7 7 8}$ \\
\hline RE2 & 0.319 & 0.226 & $\mathbf{0 . 7 6 6}$ \\
\hline RE3 & 0.310 & 0.257 & $\mathbf{0 . 7 5 1}$ \\
\hline
\end{tabular}

TABLE 4: AVE.

\begin{tabular}{l|c|} 
& AVE \\
\hline Family Enviroment & $\mathbf{0 . 6 2 7}$ \\
\hline Interest in slamicpreneur & $\mathbf{0 . 6 3 0}$ \\
\hline Religiusitas & $\mathbf{0 . 5 8 5}$ \\
\hline
\end{tabular}

Yamin (2011) argues that if the Cronbach's alpha is less than 0.50 but the value of the reliability composite is more than 0.70 then the construct can still be said to be reliable.

TABLE 5: AVE.

\begin{tabular}{|c|c|c|}
\hline & cronbach's alpha & $\begin{array}{c}\text { composite } \\
\text { reliability }\end{array}$ \\
\hline FE & 0.852 & 0.894 \\
\hline IPI & 0.854 & 0.895 \\
\hline RE & 0.646 & 0.890 \\
\hline
\end{tabular}

Based on the output above, it can be concluded that this research has reliability problem. Thus, based on testing the outer model, it can be concluded that the outer model in this study has fulfilled the specified requirements and is feasible to conduct testing to the next stage. 


\subsubsection{Inner model testing}

Inner model testing is done through R-Square analysis (R2), Multicollinearity, F-Square (F2), Q-Square (Q2) and Good of Fit (GoF). Following:

\section{R-Square (R2) Analysis}

R-Square Analysis (R2) aims to explain the proportion of the variation of the dependent variable that can be explained by all the independent variables. According to Chin R2 results of 0.67 indicates that the model is categorized as good, 0.33 is categorized as moderate while 0.19 is categorized as weak (Ghozali, 2014). Following are the results of the $\mathrm{R} 2$ test output:

Based on the results of the coefficient test, it is known that R2 of the Islamic interest variable is 0.491 . It means that the independent variables, namely the family environment and religiosity are able to explain the dependent variable that is the interest of Islamicpreneur by $49 \%$ while the remaining $51 \%$ is explained or influenced by other variables outside the model in this study. This R2 result of 0.491 according to Chin indicates that the variables in the model have a moderate relationship.

\section{Multicollinearity}

Multicollinearity analysis aims to know that a measured construct is completely different from other constructs. If the tolerance value is $<0.20$, multicollinearity is detected or if the VIP value Is $>5$ then multicollinearity can be suspected (Garson, 2016).

TABLE 6: VIP.

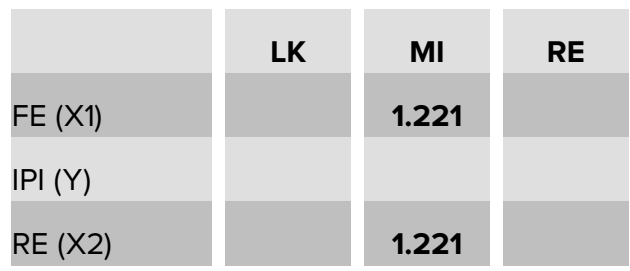

Based on the above output, it is concluded that this research is free from the problem of multicollinearity.

\section{F-Square (F2)}

This test is conducted to analysis the level of influence of the latent variable predictors whether weak, medium or large at the structural level. F2 values of 0.02 , 
0.15 and 0.35 indicate that the latent variable predictors have a weak, moderate and large influence on the structural level.

TABLE 7: F square.

\begin{tabular}{|l|c|}
\hline & Minat Islamicpreneur \\
\hline Family enviroment & $\mathbf{0 . 7 6 8}$ \\
\hline Islamicpreneur Interest & \\
\hline Religiosity & $\mathbf{0 . 0 0 1}$ \\
\hline
\end{tabular}

Based on the results of the F-Square output above, it can be seen that the influence of family environment variables on the variable interest in Islam has a large level of influence because it exceeds the value of 0.35 which is equal to 0.768 . While the religiosity variable has a weak level of influence with a value of 0.001 because it is less than 0.2 and 0.15 .

\section{Q-Square (Q2)}

This test is conducted to analysis how well the observation value is produced by the model. Q-Square value that exceeds zero (0) has a good predictive relevance value, whereas if the $Q$-Square value that is less than zero indicates that the model lacks good predictive relevance.

$$
\begin{gathered}
Q 2=1-(1-R 2) \\
Q 2=1(1-0,4912) \\
Q 2=0,241
\end{gathered}
$$

Based on the results of these calculations, the research model can be said to have good predictive relevance because it has a value that is more than zero $(0)$.

\section{Good of Fit (GoF)}

This analysis serves to evaluate the structural model and overall measurement. The GoF value category is 0.1 is categorized as small, 0.25 is categorized as medium and 0.38 is categorized as large. The following is the formula used to calculate the Goodness of Fit value:

$$
G o F=\sqrt{(\overline{(A V E)} \times \overline{(R \wedge 2)})}
$$


Based on the results of the calculations that have been done, the GoF result is 0.648 which is greater than 0.38 . Thus it can be concluded that the model built has a good Goodness of Fit. So this research model is stated as robuts.

\section{Hypothesis testing}

Research hypothesis testing is analysis by comparing t-statistics and t-table values or probability values. To test this research hypothesis uses a significance level of $5 \%$. If using the t-statistical test, the t-table at the $5 \%$ significance level is 1.96 because the sample exceeds 30 . So the HA hypothesis testing criteria is accepted and $\mathrm{HO}$ is rejected when t-statistics $>1.96$ or 2.326. Meanwhile, the HA testing criteria accepted by using probability testing is when the P-Values value is $<0.01$ or 0.05 . The following is a model of variable significance analysis obtained through bootstrapping calculations:

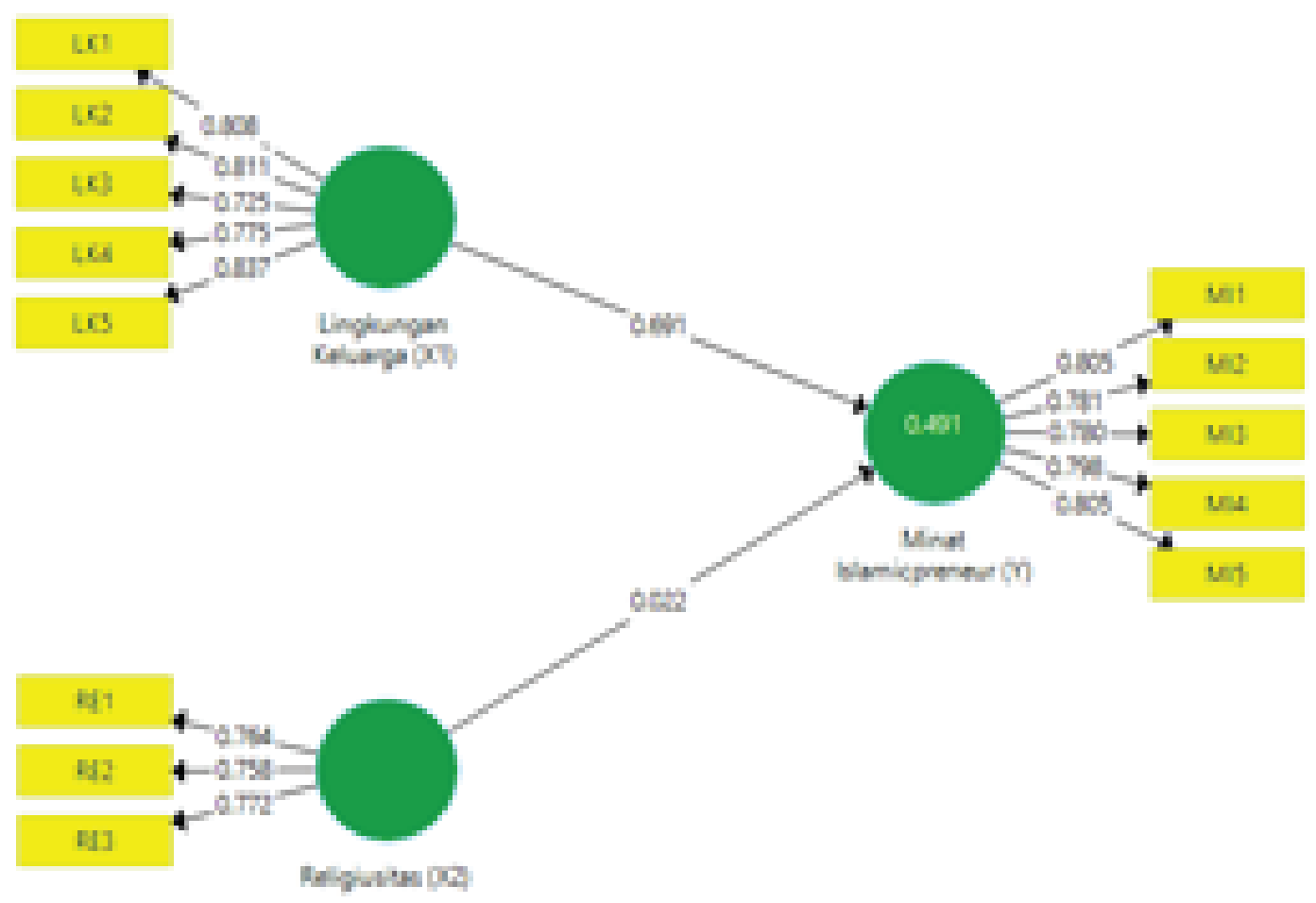




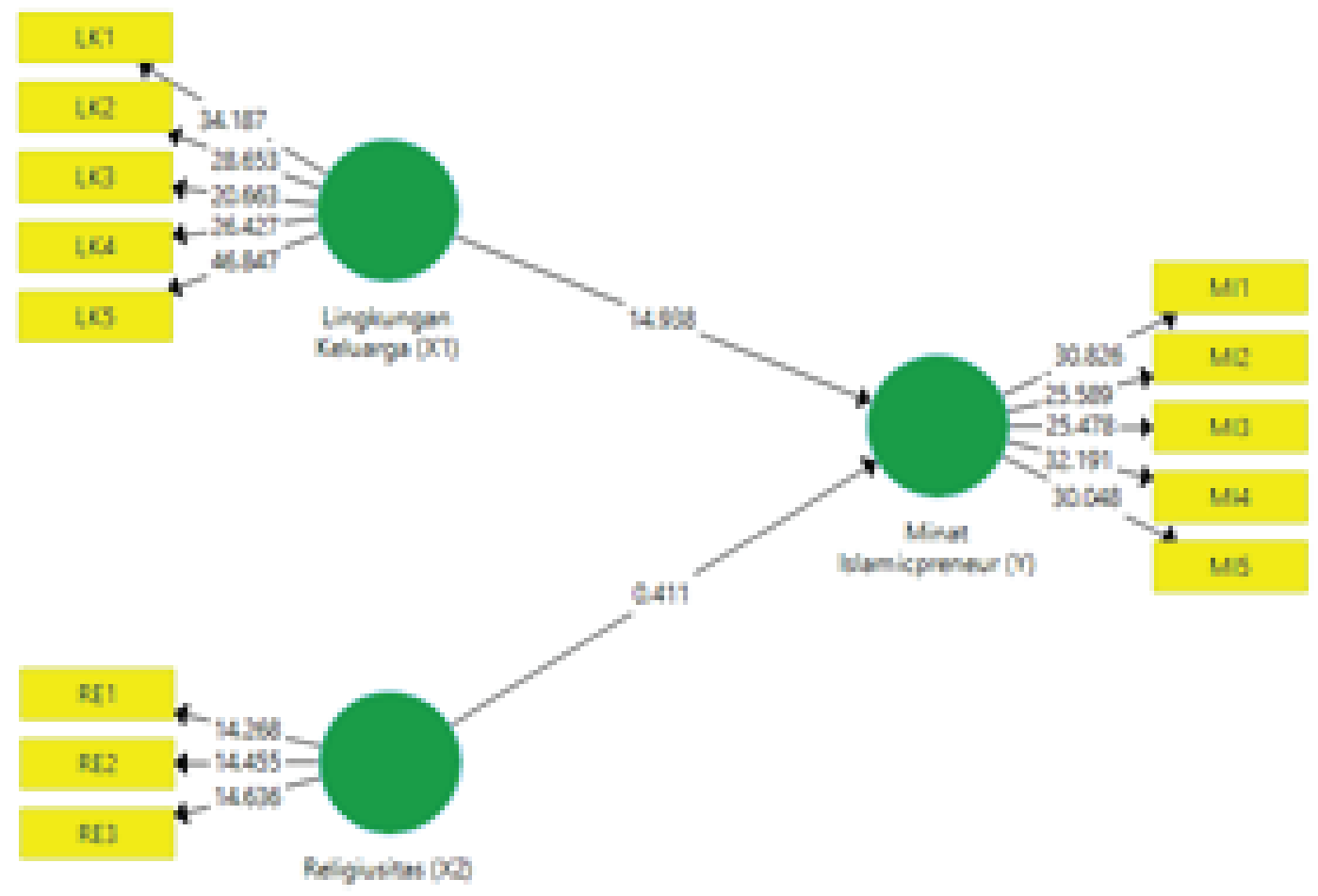

To see the acceptance or rejection of the hypothesis can be seen from the following bootstrapping report:

\section{Hypothesis testing I Influence Family Environment towards Islamicpreneur Interest.}

Based on the output path coefficients in table 4.35 it can be seen that family environment variables have a positive and significant influence on the interest of Islamicpreneur. This is evidenced by the t-statistic value with a value of 14,342 where the value is greater than 1.96 and the significance at alpha is 0.5\% (P-values $<0,005)$.

This test states that the higher the support of the family environment, the higher the interest of a student to become Islamicpreneur. Where these findings support the theory that the family environment has a significant influence on a person. This is also as explained in the convergence theory which states that the surrounding environment has an important role in individual development (Walgito, 2002). Then supported by the opinion of McCleland quoted in Wahyuningsih (2017) who said that the family environment can be a conducive environment to train and hone individual characters including the character of entrepreneurship which can then be a provision for children to begin directing their interest in the future. In addition, the findings support several results of empirical research conducted by Koranti (2013), Ayodele (2014), Maftuhah \& 
Suratman (2015), Yanti, Nuridja \& Dunya (2014), Mustapha \& Selvaraju (2015), and also Wahyuningsih, Junaidi, \& Ulfah (2017). The results of the study revealed that the family environment has a positive and significant influence on entrepreneurial interest.

\section{Hypothesis test II Influence Religiosity towards Islamicpreneur Interest}

Based on the output path coefficients in the model can be seen that the variables of religiosity do not affect the interest of Islamicreneur. This is evidenced by the t-statistic value with a value of 04.302 where the value is less than 1.96 and the significance at alpha is $0.5 \%$ (P-values $>0.005)$. Thus the results of this test reject the theory that religiosity has a positive and significant effect on entrepreneurial interest. This research is also not in line with the opinions expressed by Menzter in Juliana (2017) stating that religion has an influence on entrepreneurial motivation. In addition, this study also rejected previous studies including Balog (2013), Abdullahi (2015), Riaz (2016), and Youcef (2015) which stated that religiosity has a positive and significant influence on entrepreneurial interest.

This research is also not in line with the opinions expressed by Menzter in Juliana (2017) stating that religion has an influence on entrepreneurial motivation. In addition, this study also rejected previous studies including Balog (2013), Abdullahi (2015), Riaz (2016), and Youcef (2015) which stated that religiosity has a positive and significant influence on entrepreneurial interest.

However, this research is in line with research conducted by (Ramadhani, 2017) which states that the higher the level of religiosity does not affect the tendency of people to engage in entrepreneurial activities. Based on his research this is due to the increasingly religious individual of a Muslim, he will feel closer to Allah SWT. His closeness to Allah SWT made him believe that Allah SWT could bring sustenance even though he did not have to be an Islamic scholar. The phrase is then in line with the values known as Sufism. Some opinions then suggest that Sufism is independence, so that humans are freed from the bonds of world lust (Ismail, 2008). The same thing was also revealed by Juliana (2017) who said that the value of Sufism was seen as another world catastrophe due to avoidance of materialistic worldly affairs.

This then becomes a logical reason why the higher individual religiosity is not affected by the interest of a Muslim individual to entrepreneurship. These findings are also consistent with observations of the facts that have occurred in Indonesia and the world which prove that Indonesia as a country with the largest Muslim population in the world does not necessarily make Indonesia as a country with the largest number of entrepreneurs in the world. The 2017 Global Entrepreneurship Index ranks 90th (Global 
Entrepreneurship Index, 2017). This is evidence that Indonesia is still unable to become an entrepreneurial country.

But it does not affect the level of religiosity towards the interest to become Islamicpreneur does not mean the level of religiosity or the value of Sufism makes a Muslim person a lazy person. This is evident in several studies which state that religiosity has a positive and significant effect on the work ethic of a Muslim. As research conducted by Sulistyo (2011), Fauzan \& Tyasari (2012), and Yudiani (2016) which states that the level of religiosity has a positive and significant influence on ethos and work motivation.

In this case the career choices that are considered more valuable in the view of the individual Muslim who has a high level of religiosity are by working as an amil, teacher, lecturer, doctor and other professions who feel closer to Allah SWT. Because basically Islamic values teach every servant to work better, be quality and responsible. But it does not rule out the possibility also if a Muslim individual makes entrepreneurial activity as his choice of activity in a career. Because Rasulullah SAW also works as a merchant. Thus entrepreneurial activity can be used as one of the sunnah and forms of worship in servitude to Allah SWT. As long as the activities carried out do not make him forget about the afterlife.

\section{Conclusion}

The family environment in Islamic economics students in the city of Bandung is in the high category. The family environment also proved to have a positive and significant influence on Islamic interest in Islamic economics students in the city of Bandung. So the steps that can be taken to increase the interest of Islamic scholarship in students is that each Muslim family is expected to create an atmosphere of an Islamic family environment.

Where is the way of educating parents, relationships between families, and elements in other families can provide support and encouragement to their children to become Islamicpreneur. In addition, each family is also able to change the main set where successful families are families who can successfully educate their children who succeed in becoming civil servants. Thus the higher the influence of the family environment, the higher the interest of Islamic economics students in the State University of Bandung to become Islamicpreneur.

The level of religiosity of Islamic economic students in the city of Bandung is included in the high category. But the results of the study concluded that Religiosity does not affect the interest of Islamicpreneur in Islamic economics students in the city of Bandung. 
Therefore, it can be said that the higher the religiosity of Islamic economics students at PTN in Bandung City, then it does not affect the interest of the students to become Islamicpreneur. The recommendations that the author can design, There is a need for regular religious studies in discussing entrepreneurship in the view of Islam. As well as understanding Sufism more deeply in carrying out world activities. Because Islam as a comprehensive religion basically strongly encourages its people to do hard work without forgetting the responsibilities of the hereafter. Thus, the understanding of tasawuf understanding should only make every Muslim more enthusiastic in entrepreneurship because entrepreneurship is one of the forms of worship that has great benefits both for themselves and for others around them. Because with entrepreneurship, a Muslim will become a wealthy rich person who pays attention to the relationship of his life both in habluminnallah, habluminnanas, and habluminnanafsi.

[1] Abdullahi, A., \& Suleiman, M. (2015). Impact of Religion on On Entrepreneurial Intention Of University Students In Kano State, Nigeria. Proceedings of ICIC2015International Conference on Empowering Islamic Civilization in the 21st Century.

[2] Ahmad, H., \& Hadiyanto, A. (2014). Pendidikan Karakter Berbasis Spritualisme Islam (Tasawuf). Jurnal Studi AI-Quran Volume 10 No.1.

[3] Aisyah, M. (2014). The Influence of Religious Behavior on Consumers's Intention to Purchase Halal-Labeled Products. Business and Entrepreneurial Review.

[4] Ayodele, S. (2014). Family Background and Entreprenial Intention of Fresh Graduates in Nigeria. Journal of Poverty, Investment and Development.

[5] Azwar, S. (2006). Penyusunan Skala Piskologi. Yogyakarta: Pustaka Belajar.

[6] Balog, A., Bakerb, L., \& WaFEerb, A. (2013). Religiosity and spirituality in entrepreneurship: a review and research agenda. Association of Management, Spirituality \& Religion.

[7] BPS. (2017, Agustus). bps.go.id. Retrieved from Agustus 2017: Tingkat Pengangguran Terbuka (TPT): https://www.bps.go.id/pressrelease/2017/11/06/1377/agustus-2017-tingkat-pengangguran-terbuka--tpt--sebesar-5-50-persen.html

[8] Buchori, A. (2007). kewirusahaan. Bandung: Alfa Beta.

[9] Depkop. (2017). Wirausaha Maju, Negara Sejahtera. koperasi.kulonprogokab.go.id.

[10] Fahruddin. (2016). Tasawuf Sebagai Upaya Membersihkan Hati Guna Mencapai Kedekatan dengan Allah. Jurnal Pendidikan Agama Islam- Ta'lim Vol. 14.

[11] Fauzan. (2013). Pengaruh Religiusitas Terhadap Etika Berbisnis. Jurnal Manajemen dan Kewirusahaan. 
[12] Fauzan, \& Tyasari, I. (2012). Pengaruh Religiusitas dan Etika Kerja Islami Terhadap Motivasi Kerja. Jurnal Ekonomi Modernisasi Vol. 8, 4.

[13] Fuadi. (2009). Hubungan minat berwirausaha dengan prestasi praktikkerja industri siswa kelas XII teknikotomotif SMK Negri 1 Adiwerna Kabupaten Tegal. Jurnal PTM.

[14] Garson, G. D. (2016). Partial Least Squares: Regression and Structural Equation Models. USA: Statistical Publishing Associates.

[15] Ghozali, I. (2014). Structural Equal Modeling Metode Alternatif dengan Patrial Least Square (PLS). Semarang: Badan Penerbit Universitas Diponegoro Semarang.

[16] Hidayat, M., \& Alhifni. (2017). Faktor-faktor yang Mempengaruhi Motivasi Mahasiswa Menjadi Entrepreneur Syariah. Jurnal Syarikah.

[17] Hisrich, P. S. (2008). Kewirusahaan Edisi 7. Edisi Bahasa Indonesia. Jakarta: Salemba Empat.

[18] Indarti, \& Rostianti. (2008). Intensi Kewirausahaan Mahasiswa: Study Perbandingan antara Indonesia, Jepang dan Norwegia. Jurnal Ekonomika dan Bisnis Indonesia.

[19] Ismail. (2008). Ensiklopedia Tasawuf Jilid 1. Bandung: Angkasa.

[20] Juliana. (2017). Syariahpreneur dalam mewujudkan kesejahteraan Masyarakat. Corbooks: Bandung.

[21] Kemendagri. (2013). Perkembangan dan Solusi Masalah Pengangguran di Indonesia. http://keuda.kemendagri.go.id.

[22] Kompas. (2017). Agustus 2017, Jumlah Pengangguran Naik Menjadi 7,04 Juta Orang. Kompas.com.

[23] Koranti, K. (2013). Analisis Pengaruh Faktor Eksternal dan Internal Terhadap Minat Berwirausaha. Proceeding PESAT (Psikologi, Ekonomi, Sastra, Arsitektur dan Teknik Sipil).

[24] László Szerb, Erkko Autio, Ainsley Lloyd. (2017). Global Entrepreneurship Index. London: GEDI (Global Entrepreneurship and Development Institute).

[25] Maftuhah, R., \& Suratman, B. (2015). Pengaruh Efeksi Diri, Lingkungan Keluarga, dan Pengetahuan Kewirusahaan Terhadap Minat Berwirausaha Siswa SMK di Sidoarjo. Jurnal Ekonomi dan Kewirusahaan.

[26] Makhrus, \& Cahyani, P. D. (2017). Konsep Islamicpreneurship dalam Upaya Mendorong Praktik Bisnis Islami. Islamadina: Jurnal Pemikiran Islam.

[27] Merdeka. (2017). HIPMI sebut hanya 4 persen dari 5 juta mahasiswa mau jadi pengusaha. Merdeka.com.

[28] Muhdar. (2015). Potret Ketenagakerjaan, Pengangguran, dan Kemiskinan di Indonesia: Masalah dan Solusi. Al-Buhuts. 
[29] Mustapha, M., \& Selvaraju, M. (2015). Personal Attributes, Family Influence, Entrepreneurship Education and Entrepreneuship Inclination Among University Student. Kajian Malaysia.

[30] Nurkholifah, \& Ita. (2014). Membangun Muslim Entreprenurship: Dari Pendekatan Konvensional ke Pendekatan Syariah. Jurnal IAIN Pontianak.

[31] Octavianica, A., Rusman, T., \& Nurdin. (2016). Pengaruh Motivasi Berwirausaha Serta Lingkungan Internal dan Lingkungan Eksternal Terhadap Minat Berwirausaha. Jurnal Universitas Lampung.

[32] Ramadhani, A. (2017). Pengaruh Tingkat Religiusitas Terhadap Entrepreneurship. Tesis Universitas Gadjah Mada.

[33] Republika. (2015). Inilah 10 Negara dengan Populasi Muslim Terbesar di Dunia. Republika.co.id.

[34] Republika. (2017). Apindo Khawatirkan Minimnya Pengusaha Muslim di Indonesia. https://republika.co.id/berita/ekonomi/makro/17/03/28/onibfy365apindo-khawatirkan-minimnya-pengusaha-muslim-di-indonesia.

[35] Republika. (2017). KPPU: Pengusaha di Indonesia Hanya 1,6 Persen Jumlah Populasi. Republika.co.id.

[36] Riaz, Q., Farrukh, M., Rehman, S., \& Amir. (2016). Religion and Entrepreneurial Intentions: an Empirical Investigation. International Journal of Advanced and Applied Sciences.

[37] Siam, \& Ibrahim, M. (2015). The Influence of Entrepreneurial Skills, Enviromental Suport, And Motivation Factors on Entrepreneurial Intention. Jurnal Universiti Utara Malaysia.

[38] Slameto. (2010). Belajar dan Faktor-faktor yang Mempengaruhinya. Jakarta: Rineka Cipta.

[39] Sulistyo, H. (2011). Peran Nilai Religiusitas Terhadap Kinerja Karyawan dalam Organisasi. Media Riset Bisnis dan Manajemen, 15.

[40] Sungkar, L. (2010). Consumer Awareness: Thoughts and Trends across the Globe. The Halal Journal.

[41] Wahyuningsih, T., Junaidi, \& Ulfah, M. (2017). Pengaruh Lingkungan Keluarga dan Kepribadian Wirausaha Terhadap Minat berwirausaha Siswa Kelas XI SMKN Pontianak. Jurnal Ekonomi Utan Pontianak.

[42] Walgito, B. (2002). Pengantar Psikologi Umum. Yogyakarta: Adi.

[43] Wulandari, N., Rosida, R., Cakhyane, A., \& Aliandawati, N. (2016). Optimization of Cash Waqf in Developing Creative Industry: An Effort to Create Shariacreativepreneur. Atlantis Press. 
[44] Yamin, S., \& Kurniawan, H. (2011). Generasi Baru Mengolah Data Penelitian dengan Partial Least Square Path Modeling: Aplikasi dengan Software XLSTAT, SmartPLS, dan Visual PLS. Jakarta: Salemba Infotek.

[45] Yanti, Nuridja, I., \& Dunia, I. (2014). Pengaruh Lingkungan Keluarga Terhadap Berwirausaha Siswa Kelas XI SMK Negeri 1 Singaraja. Jurnal Universitas Pendidikan Ganesha.

[46] Youcef, S., Djelloul, C., \& Mokhtar, I. (2015). The Impact of Religious Dimension on Entrepreneurial Intention. Economics World: David Publishing.

[47] Yudiani, E. (2016). Etos Kerja Islami Dosen Faultas Ushluhuddin dan Pemikiran Islam UIN Raden Fattah Palembang Ditinjau dari Religiusitas. PSIKIS- Jurnal Psikologi Islami Vol 2, 13. 